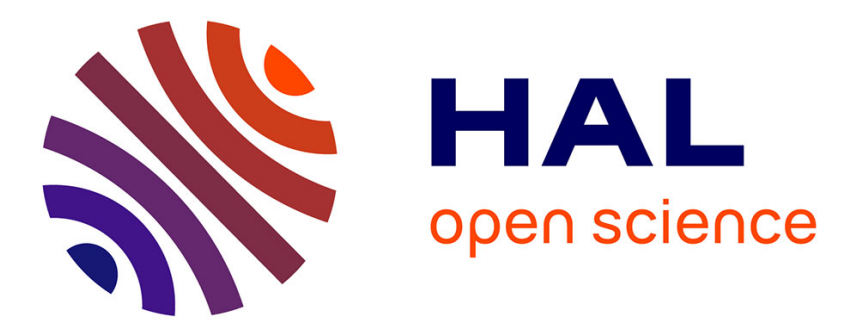

\title{
A tale of many jurisdictions: how universal jurisdiction is creating a transnational judicial space
}

\author{
Sandrine Lefranc
}

\section{To cite this version:}

Sandrine Lefranc. A tale of many jurisdictions: how universal jurisdiction is creating a transnational judicial space. Journal of Law and Society, 2021, 48 (4), pp.573-594. 10.1111/jols.12328 . hal03470364

\section{HAL Id: hal-03470364 \\ https://hal-sciencespo.archives-ouvertes.fr/hal-03470364}

Submitted on 23 Dec 2021

HAL is a multi-disciplinary open access archive for the deposit and dissemination of scientific research documents, whether they are published or not. The documents may come from teaching and research institutions in France or abroad, or from public or private research centers.
L'archive ouverte pluridisciplinaire HAL, est destinée au dépôt et à la diffusion de documents scientifiques de niveau recherche, publiés ou non, émanant des établissements d'enseignement et de recherche français ou étrangers, des laboratoires publics ou privés.

\section{(ㅇ)(1) $\$$}

Distributed under a Creative Commons Attribution - NonCommercial - NoDerivatives| 4.0 


\title{
A tale of many jurisdictions: how universal jurisdiction is creating a transnational judicial space
}

\author{
Sandrine Lefranc \\ CEE, Centre national de la recherche scientifique, Sciences Po Paris, 28 rue des Saints Pères, Paris 75007, France \\ In : Journal of Law and Society (ISSN : 0263-323X, e-ISSN : 1467-6478), December 2021, vol. 48, \\ Issue 4, p. 573-594.
}

First published: 17 November 2021

DOI: $10.1111 /$ jols. 12328

\begin{abstract}
Universal jurisdiction (UJ), which not very long ago seemed condemned to extinction, is now becoming rou-tine. It has been endorsed by 109 states, and the num-ber of prosecutions is increasing. This article is based on an ethnographic study of the recent trial in France of Pascal Simbikangwa, a Rwandan accused of participat-ing in the genocide against the Tutsi in 1994. Using the concepts of 'vernacularization' and 'transnational legal orders', it shows how $\mathrm{UJ}$ is creating a transnational judi-cial space (TJS). Involving both partisan and ordinary actors, this process is fraught with multiple conflicts. Although UJ does not participate in the dissemination of a uniform definition of genocide, it makes various juris-dictions work together. This fragmented transnational justice is paradoxically contributing to the integration of national legal systems.
\end{abstract}

\section{1 | INTRODUCTION}

More than three-quarters of the Tutsi population died in the space of just 100 days, between April and July 1994, in Rwanda. At least 800,000 people were killed by government-directed gangs of Hutu soldiers and police, with the complicity of a large part of the population. ${ }^{1}$ Hutu opponents were also murdered. There is no doubt about the genocidal nature of the massacres perpetrated

\footnotetext{
${ }^{1}$ J.-P. Kimonyo, Rwanda's Popular Genocide: A Perfect Storm (2016); S. Straus, The Order of Genocide: Race, Power, and War in Rwanda (2006).
} 
against the Tutsi. More than 25 years later, it is certainly the most frequently judged genocide. In 1998, the International Criminal Tribunal for Rwanda (ICTR) became the first international criminal jurisdiction to condemn a genocide. ${ }^{2}$ On 16 June 2006, it stated that this genocide is a 'fact of common knowledge. ${ }^{3}$ Around one million people were tried by the gacaca popular courts set up by the Rwandan state. ${ }^{4}$ Alongside the ICTR and the gacaca trials, which respectively ceased to operate after 2012 and 2015, many European courts have found people guilty of crimes against humanity. These genocidaires have been the subject of proceedings initiated simultaneously in Europe, in Rwanda, and before international bodies.

Acting on behalf of the ICTR, the French courts tried a Rwandan who resided in France. ${ }^{5}$ On 14 March 2014, the twentieth anniversary of the genocide against the Tutsi, Pascal Simbikangwa, a former army captain accused of belonging to radical networks that instigated the genocide, was found guilty of crimes against humanity and of genocide and sentenced to 25 years in prison (a decision upheld on appeal on 3 December 2016). Pressure from organizations representing the victims (such as the Collectif des Parties Civiles pour le Rwanda and Ibuka France) contributed significantly to the judgment and sentence. ${ }^{6}$ The trial was deemed 'historic'. ${ }^{7}$ Two other men residing in France were subsequently found guilty of crimes against humanity and of genocide. Some 30 other cases are being investigated. In France, as in other countries, universal jurisdiction (UJ) is flourishing.

UJ is a legal tool that allows a national court to rule on international crimes, regardless of the place of their commission and the nationality of the perpetrators and victims. It has long been described as a source of confrontation between international law and states' Realpolitik. According to Slaughter, a 'new world order' and a 'global jurisprudence' could be built thanks to 'transjudicial deliberation' and 'harmonization networks'. ${ }^{8}$ International and domestic courts could act in a complementary way to deliver a 'more objective and even-handed justice', as foreign judges have 'no prior interest in the prosecution'. 9 Therefore, the strengthening of links between states, international tribunals, and private actors such as non-governmental organizations (NGOs) and the unification of legal standards and categories seem to be inventing a legal system without borders, making an inescapable global justice possible.

\footnotetext{
${ }^{2}$ ICTR, Judgment, Prosecutor v. Akayesu, ICTR-96-4-T [2 September 1998].

${ }^{3}$ ICTR Appeals Chamber, Prosecutor v. E. Karemera et al., ICTR-98-44-AR-73(C) [16 June 2006] 14.

${ }^{4} \mathrm{H}$. Dumas, Le génocide au village: le massacre des Tutsi au Rwanda (2014); P. J. Clark, The Gacaca Courts, Post-Genocide Justice and Reconciliation in Rwanda: Justice without Lawyers (2010).

${ }^{5}$ Loi no. 96-432 du 22 mai 1996 portant adaptation de la législation française aux dispositions de la Résolution 955 du Conseil de sécurité des Nations unies.

${ }^{6}$ The Collectif des Parties Civiles pour le Rwanda (Civil Plaintiffs Collective for Rwanda, CPCR) is an organization that was created in 2001 by Dafroza and Alain Gauthier. Its goal is to help to prosecute criminals residing in France. Ibuka ('Remember') is an organization that works to build a memory of the genocide against the Tutsi in Rwanda by supporting survivors and pursuing criminals. It was founded in Belgium in August 1994 and then in Switzerland and Rwanda in 1995 , and finally in France in 2002.

${ }^{7}$ See for example Guardian, 'Rwanda Genocide Trial Opens in France' Guardian, 4 February 2014, at <https:// www.theguardian.com/world/2014/feb/04/rwanda-genocide-trial-opens-france-pascal-simbikangwa>; New York Times, 'A Genocide Trial in Paris' New York Times, 18 March 2014, at <https://www.nytimes.com/2014/03/19/ opinion/a-genocide-trial-in-paris.html>.

${ }^{8}$ A. M. Slaughter, A New World Order (2004) 150.

${ }^{9}$ K. J. Fisher, Moral Accountability and International Criminal Law: Holding Agents of Atrocity Accountable to the World (2012) 118-119.
} 
UJ is deemed to have created a global judicial system by casting a densely woven net over these perpetrators, including heads of state. Despite their simple, underlying passive personality principle, ${ }^{10}$ the international proceedings brought in 1998 against Augusto Pinochet enabled the reactivation of the prosecutions in Chile but also, more broadly, the 'globalization of accountability for crimes carried out by governmental officials. ${ }^{11}$ A 'justice cascade' since the end of the Cold War would have favoured the unification of international law and made amnesties less acceptable. ${ }^{12}$ Each national court can now act as the guardian of another national court at a distance as required in the principle of complementary jurisdiction stated by the 1998 Rome Treaty, which created the International Criminal Court (ICC).

In this respect, the French courts may have become agents of a global justice. In a world order where national courts directly apply international law without restrictions in terms of residence or immunity, victims of crimes against humanity would feel empowered. The world could thereby become a unified legal and judicial space where perpetrators, hiding behind false identities, can be unmasked by genocidaire 'hunters' who have also become mobile and able to investigate and file legal action, even before foreign courts. The Gauthiers, the couple who founded the CPCR, which is behind the prosecution of most of the Rwandan cases in France, and who attended every single hearing, are emblematic of this struggle.

Realist scholars in international relations find this scenario frightening. Considering the raison d'état to be inviolable and peace to be the most desirable goal, they tend to see UJ as a threat to the interests of powerful states. ${ }^{13}$ They defend the necessity and inevitability of the submission of international law to the sovereign order of states. Their critiques are founded on a fear of 'the spectre of fragmentation' of international law. ${ }^{14}$ On such a basis, UJ is doomed to disappear. The possibility that was engendered in Belgium for the unconditional application of UJ, for example, actually signalled its end. More than 30 complaints against high-ranking politicians (including Ariel Sharon, Donald Rumsfeld, and George H. W. Bush) provoked diplomatic incidents and led to direct pressure from the United States to repeal the law in 2003.

Having been mobilized against incumbent heads of states and nationals of powerful democratic countries, UJ has in effect been brought back under control. Pitting human rights activists against champions of state sovereignty, it has ignited the debate on international law, but with very weak judicial effects. Legislators have imposed conditions. In France, for example, the Act of 9 August 2010 defined the jurisdiction of French courts for crimes within the jurisdiction of the ICC, introducing various conditions including the habitual residence of the alleged perpetrator on French soil, the criminalization of the acts by the law of the state where they were committed, the monopoly of prosecution by the public prosecutor, and a subsidiarity with other jurisdictions. ${ }^{15}$

\footnotetext{
${ }^{10}$ The passive personality principle allows states to claim jurisdiction to try a foreign national for offences committed abroad that affect its own citizens.

${ }^{11}$ G. Halmai, 'Domestic Courts and International Human Rights' in The SAGE Handbook of Human Rights, eds A. Mihr and M. Gibney (2014) 749, at 754.

${ }^{12}$ E. Lutz and C. Reiger (eds), Prosecuting Heads of State (2009).

${ }^{13}$ H. Kissinger, 'The Pitfalls of Universal Jurisdiction: Risking Judicial Tyranny' (2001) 7-8 Foreign Affairs 86; J. Snyder and L. Vinjamuri, 'Trials and Errors: Principle and Pragmatism in Strategies of International Justice' (2004) 28 International Security 5; T. Kluwen, 'Universal Jurisdiction in Absentia before Domestic Courts Prosecuting International Crimes: A Suitable Weapon to Fight Impunity?' (2017) 8 Goettingen J. of International Law 7.

${ }^{14}$ W. Schabas, 'Synergy or Fragmentation: International Criminal Law and the European Convention on Human Rights' (2011) 9 J. of International Criminal Justice 613.

${ }^{15}$ Code de procédure pénale, Art. 689-1, created by Loi no. 2010-930 du 9 août 2010 portant adaptation du droit penal à l'institution de la Cour pénale internationale, Art. 8.
} 
TA B L E 1 Criminal prosecutions against Rwandans in national foreign courts

\begin{tabular}{|c|c|c|c|}
\hline Country & $\begin{array}{l}\text { Number of Rwandans } \\
\text { prosecuted (starting date) }\end{array}$ & $\begin{array}{l}\text { Number of } \\
\text { extraditions }\end{array}$ & $\begin{array}{l}\text { Other Rwandan } \\
\text { cases ongoing }\end{array}$ \\
\hline Belgium & $11(2001)$ & & 35 \\
\hline Canada & $\begin{array}{l}2(2013) \\
1 \text { acquittal }\end{array}$ & 2 & 1 \\
\hline Denmark & & 2 & \\
\hline Finland & $1(2010)$ & & \\
\hline France & $\begin{array}{l}4(2014) \\
1 \text { dismissal }\end{array}$ & 6 refusals & Around 30 \\
\hline Germany & $4(2011)$ & & \\
\hline Netherlands & $2(2011)$ & 4 & \\
\hline Norway & $1(2015)$ & 2 & 1 \\
\hline Sweden & $5(2014)$ & & \\
\hline Switzerland & $1(2001)$ & & \\
\hline Uganda & & 1 & \\
\hline United Kingdom & & 5 refusals & \\
\hline United States & $\begin{array}{l}3 \text { (1996) } \\
1 \text { civil, } 1 \text { dismissal }\end{array}$ & 4 & \\
\hline
\end{tabular}

$\mathrm{UJ}$ is nevertheless becoming routine, at the very moment that it seemed to be being weakened. It has been endorsed by 109 states. The number of prosecutions is increasing; in its annual reports on UJ, the NGO TRIAL (TRack Impunity ALways) notes the steady increase in the number of cases (about 60 per year) and prosecuting countries (12 in 2014, 18 in 2020). Of course, the involvement of national judicial systems still reflects state policies, in the continuity of colonial pasts (for France and Belgium) or of roles played on the international scene; Germany is, for example, the champion of trials against Syrians. However, there has been a diversification of the countries where the crimes were committed (numbering 28, in Africa, the Middle East, and Asia, but also in Europe and America). ${ }^{16}$ Many European courts have found Rwandans guilty of genocide (see Table 1). In total, national courts try more individuals than international courts do. For example, the ICC has only tried 30 cases involving 14 countries, almost all of them African.

The spread of this more conditional and modest form also broadens the range of individuals prosecuted. A global net catches more fish. Who, in fact, are the Rwandan people who are tried in Europe? Some high-ranking politicians, but mostly a number of mid-level public officials. UJ consequently instituted a division of labour between apparently well-coordinated levels of justice. At the ICTR, it would be the 'big fish' who had instigated the genocide; in the gacaca courts, one's neighbours and the heads of local criminal gangs; in European and Canadian courts, the local bosses or mid-level national figures who were living in exile (see Table 2). ${ }^{17}$ In fact, each level of jurisdiction was able to try parties of greater or lesser importance, whose title did not always match the actual extent of their power.

\footnotetext{
${ }^{16}$ TRIAL International, 'Compétence universelle' TRIAL International, at <https://trialinternational.org/fr/topicspost/competence-universelle/>.

${ }^{17}$ M. Langer, 'The Diplomacy of Universal Jurisdiction: The Political Branches and the Transnational Prosecution of Inter-national Crimes' (2011) 105 Am. J. of International Law 1.
} 
TAB LE 2 A decentralized justice for the genocide against the Tutsi

\begin{tabular}{|c|c|c|c|}
\hline & ICTR & Foreign courts & $\begin{array}{l}\text { Rwandan criminal } \\
\text { courts and gacacas }\end{array}$ \\
\hline $\begin{array}{l}\text { Number of } \\
\text { individuals } \\
\text { tried }\end{array}$ & 93 tried, 62 sentenced & $\begin{array}{l}\text { Approximately } 25 \\
\text { sentenced and } 60 \text { other } \\
\text { current cases, in } 12 \\
\text { countries }\end{array}$ & $\begin{array}{l}\text { Criminal justice system: } \\
\text { approximately } 12,000 \\
\text { Gacacas: } 1,960,000\end{array}$ \\
\hline $\begin{array}{l}\text { Levels of } \\
\text { responsibility }\end{array}$ & $\begin{array}{l}\text { High-ranking officials, } \\
\text { grouped by role, and } \\
\text { some mid-level officials }\end{array}$ & $\begin{array}{l}\text { Mostly mid-level officials } \\
\text { and some high-ranking } \\
\text { officials }\end{array}$ & All levels of responsibility \\
\hline
\end{tabular}

(Sources: H. Dumas, Le génocide au village: le massacre des Tutsi au Rwanda (2014); H. Nyseth Brehm et al., 'Genocide, Justice, and Rwanda's Gacaca Courts' (2014) 30 J. of Contemporary Criminal Justice 333; author's data).

These partly routinized proceedings are pursuing less prominent alleged criminals than the major trials of heads of state described in the literature. They target people with varied responsibilities, whose political role was uncertain and whose behaviour was ambivalent. For example, Simbikangwa is a former army captain and a member of the extended family of the late President Juvénal Habyarimana, and was suspected of belonging to radical networks that formed around the government in power before the genocide against the Tutsi. He was not, however, on the list of the persons indicted by the ICTR. The role that he played during the atrocities is, as I show later, difficult to pin down.

Along with this growth in cases, the actual modalities of UJ have changed. In contrast to the previously isolated proceedings against powerful people who were not tried anywhere else, UJ makes disparate jurisdictions act together, on the basis of the principle of complementarity. International and national courts, in competition or in solidarity and at different paces, are involved in the trial of the genocide against the Tutsi. The same people are in fact prosecuted in Rwanda, in Tanzania (where the ICTR had its headquarters), and in one of the European capitals. They are denounced or defended by the same witnesses. The proceedings are intertwined, one accelerating or slowing down the other. Arrest warrants issued by the ICTR or by the Rwandan courts have contributed to this cross-fertilization and accelerated some proceedings in Europe. Extradition requests sometimes generate a great deal of back and forth. ${ }^{18}$ For example, Father Wenceslas Munyeshyaka, a refugee in France, was the subject of a complaint as early as July 1995. The ICTR, after issuing two arrest warrants, relinquished jurisdiction in favour of the French judicial system, but the Court of Cassation put an end to the proceedings in 2019.

This intertwining of proceedings began as early as 1995, when the newly created ICTR relied on Belgian and Swiss investigations. What is new, however, is that stable mechanisms have been established. The International Residual Mechanism for Criminal Tribunals, opened in 2012 for the ICTR, is charged with the tracking and prosecution of the eight remaining accused persons who are still at large. It can conduct appeals proceedings and is currently monitoring five cases referred by the ICTR to national courts. Does this coordination mechanism create a truly integrated international legal order? European domestic judicial systems have indeed established collaborations, with international criminal courts as well as with other national jurisdictions, which gradually become routine. Are we witnessing the establishment of a decentralized justice?

\footnotetext{
${ }^{18}$ The French Supreme Court denies extradition requests on the basis that Rwanda had not criminalized genocide and crimes against humanity at the time that the offences took place. The United Kingdom High Court does the same on the grounds that it would violate the right to a fair trial.
} 
While these legislative intertwining and coordination arrangements have been identified, their effects on trials are not well known. The Tutsi genocide has been judged simultaneously in thousands of courts, including around 12,000 gacaca courts. Witnesses, defendants, and victims but also some experts, investigators, and judges travel from one court to another. The decisions of one court affect proceedings in another. Evidence given before one judge binds witnesses when they appear before another. Justice is built and rendered in a network, and the meaning of the concepts of genocide and crimes against humanity evolves throughout the process.

\section{2 | WITH WHICH THEORETICAL TOOLS CAN WE ANALYSE A NETWORKED JUSTICE? VERNACULARIZATION AND TRANSNATIONAL LEGAL ORDERS}

How can we account for such a networked justice? Common interpretations of UJ as a component of a neo-imperial order where law would be defined by great powers or a product of a top-down uniformization of law, 'in cascade', are of little use. ${ }^{19}$ Two concepts are more enlightening: that of 'vernacularization', forged by Merry from a new legal realism perspective, on the one hand, and that of 'transnational legal orders' (TLOs), elaborated by Halliday and Shaffer in a more neoinstitutionalist approach, on the other.

Merry has emphasized the importance of the domestic appropriation of international human rights: '[T]ransnational approaches are adopted by local actors and adapted for use at home ... As these ideas are appropriated around the world, they are remade in the vernacular. ${ }^{20}$ The concept of TLOs is also useful. Halliday and Shaffer propose to shift 'attention from a dualist orientation toward international law and national law to a focus on how legal norms are developed, conveyed, and settled transnationally, integrating both bottom-up and top-down analyses' ${ }^{21}$ TLOs are defined as 'a collection of formalized legal norms and associated organizations and actors that authoritatively order the understanding and practice of law across national jurisdictions' ${ }^{22}$ What this concept adds to that of vernacularization is its special attention to recursivity and interactive processes. ${ }^{23}$ Numerous interactions between the various national and international levels facilitate local appropriations.

These two theoretical frameworks allow us to better understand the complex processes, involving a diversity of actors, that construct international legal orders. They provide a more nuanced account than the usual descriptions of a struggle for or against UJ that sets human rights activists and defenders of state sovereignty in opposition. Nevertheless, these models still emphasize vertical processes - whether top down or bottom up - of appropriation of the norms that are promoted by international organizations. The actors whom they consider are norm entrepreneurs, with specialized skills and strong beliefs.

\footnotetext{
${ }^{19}$ F. Cowell, 'Inherent Imperialism: Understanding the Legal Roots of Anti-Imperialist Criticism of the International Criminal Court' (2017) 15 J. of International Criminal Justice 667; Lutz and Reiger (eds), op. cit., n. 12.

${ }^{20}$ S. E. Merry, 'New Legal Realism and the Ethnography of Transnational Law' (2006) 31 Law \& Social Inquiry 975, at 990-991.

${ }^{21}$ T. C. Halliday and G. Shaffer, 'Transnational Legal Orders' in Transnational Legal Orders, eds T. C. Halliday and G. Shaffer (2015) 1, at 3.

22 Id., p. 9.

${ }^{23}$ Id., p. 4, p. 15.
} 
Highlighting the current strengthening of UJ, this article sheds new light on vernacularization and TLO building. Indeed, UJ establishes other dimensions of transnational law: equally complex, but much more horizontal, constructed in local spaces, articulating standards, procedures, and practices in and around courts, and involving partisan and specialized actors (human rights and victims' organizations ${ }^{24}$ ) alongside other more ordinary actors (including those drawn at random to form assize courts).

UJ does not produce, in what I propose to call transnational judicial spaces (TJSs), an integrated international law, but rather a transnational space of frictions, ${ }^{25}$ where different beliefs, cultures, and rationalities coexist - unlike 'transnational advocacy networks', which share beliefs and rationalities. ${ }^{26}$ Is this 'fragmentation'? ${ }^{27}$ In some respects, yes, as is evident from the reinterpretation of the category of genocide through local procedures and norms. However, this transnational space is also what makes a new form of justice flourish; local appropriations provoke a misalignment with international law, while allowing for horizontal alliances, strengthening mobilizations, and consolidating the transnational practice of law.

\section{3 | METHODOLOGY}

UJ trials are TJSs. To explore them, we need specific methodological approaches. Studies based on primary data are rare - even though legal characterization processes may be well described for some cases. ${ }^{28}$ Halliday and Shaffer recognize that 'what happens beyond formal adoption' of the transnational norms is an empirical void. ${ }^{29}$ I thereby propose to observe these trials from inside the courtroom and consider the interactions as they take place. New legal realism explores law as it is practised in everyday life and built by local activists doing their best to translate international norms, pragmatically, in asymmetrical and conflictive social environments. ${ }^{30}$ Merry proposes, in particular, transnational and multi-sited ethnographic research that 'tracks the flows of people, ideas, laws, and institutions across national boundaries and examines particular nodes and sites within this field of transnational circulation', especially focusing on small spaces of interaction

\footnotetext{
${ }^{24}$ Like Merry, I met many local activists entering into a pragmatic and strategic struggle within often reticent environments. In addition to the CPCR and Ibuka France already mentioned, the International Federation of Human Rights Leagues (FIDH), the Ligue contre le racisme et l'antisémitisme (LICRA, the League against Racism and Anti-Semitism), and Survie were civil litigants in the Simbikangwa trial. In France, individuals can file a criminal complaint if they have personally suffered a harm directly caused by an offence. NGOs can file a complaint if they are acting on behalf of a victim or in their own right.

${ }^{25}$ A. L. Tsing, Friction: An Ethnography of Global Connection (2005).

${ }^{26}$ M. E. Keck and K. Sikkink, Activists beyond Borders: Advocacy Networks in International Politics (1998).

${ }^{27}$ Schabas, op. cit., n. 14.

${ }^{28}$ M. Kimpimaki, 'Genocide in Rwanda: Is It Really Finland’s Concern?' (2011) 11 International Criminal Law Rev. 155; R. J. Currie and I. Stancu, 'R. V. Munyaneza: Pondering Canada’s First Core Crimes Conviction' (2010) 10 International Criminal Law Rev. 829.

${ }^{29}$ Halliday and Shaffer, 'Researching Transnational Legal Orders', in op. cit., n. 21, p. 507, at p. 507.

${ }^{30}$ S. E. Merry and P. Levitt, 'Remaking Women's Human Rights in the Vernacular: The Resonance Dilemma' in Rethinking Gender Equality in Global Governance, eds L. Engberg-Pedersen et al. (2019) 146. See also Y. Dezalay and B. Garth, The Internationalization of Palace Wars: Lawyers, Economists, and the Contest to Transform Latin American States (2002).
} 
where meanings are produced. ${ }^{31}$ Instead of her 'deterritorialized ethnography', however, I opt for a 'reterritorialized ethnography' that enables a thick description of the way in which people enter into the process and interact with each other - thicker than a panoramic multi-country study would allow.

This research is centred on an ethnography of the courts. I rely on a complete participatory observation of the Simbikangwa trial and the ensuing appeals proceedings. I spent approximately 600 hours (over the course of approximately 12 weeks) immersed in the Cours d'Assises (Assize Courts) of Paris and Bobigny. I took note in written form of all of the formal interactions during the hearings, but also the exchanges witnessed all day long, and our own informal exchanges with lawyers, magistrates, police officers, bailiffs, translators, civil parties, and families, maintaining as far as possible a position of neutrality to enable continued contact with all of the parties in an increasingly tense context - all this in French, which is the author's native language. This notebook was supplemented each evening with analyses in the margins in order to become a field journal. Since the proceedings are not transcribed or recorded, one must be present in the courtroom throughout the entire trial in order to have a complete record of the exchanges. ${ }^{32}$ This wealth of material was collected to ascertain not the main stakeholders' ex ante reasons and motives, but the actual interactions between all of the people in the room (as proposed by the anthropological and socio-legal approaches derived from the tradition of judicial ethnography). ${ }^{33}$

I also analysed relevant laws and the decisions of courts and investigating judges, around 120 articles from four newspapers (Le Monde, Libération, Le Parisien, and Le Figaro), main television and radio news programmes, and writings by social scientists and activists (mainly reports from human rights organizations ${ }^{34}$ and victims' associations ${ }^{35}$ ) in relation to the trials studied. ${ }^{36} \mathrm{I}$ also examined the judicial decisions in five other European countries where Rwandan trials were organized. Other complementary methods were used. First, I interviewed eight parties to the trials (judges, lawyers, and civil parties) to better understand the way in which they perceived the facts put before the courts and how they experienced the trials. Second, I collected data about the trajectories of defence lawyers, in France but also in other UJ proceedings and in the ICTR, which allowed us to better understand how and why these actors engage in TJSs. ${ }^{37}$

\footnotetext{
${ }^{31}$ Merry, op. cit., n. 20, p. 976.

${ }^{32}$ Criminal trials are oral proceedings; recording is prohibited but note taking is allowed. Handwritten notes cannot be processed by means of textual analysis software. Indeed, interactions and quotations do not form a uniform text, especially when several languages coexist. Gestures and looks are also important elements for analysis. See the grounds of the first decision: Cour d'Assises, Cour d'Assises de Paris statuant en première instance, feuille de motivation, Affaire Pascal Senyamuhara SAFARI alias Pascal SIMBIKANGWA fait au Palais de Justice de Paris le 14 mars 2014.

${ }^{33}$ C. Besnier, 'La Cour d'Assises: approche ethnologique du judiciaire' (2007) 54 Droit et Cultures 179; M. M. Feeley, The Process Is the Punishment: Handling Cases in a Lower Criminal Court (1979).

${ }^{34}$ I made a systematic survey of the public reporting of Human Rights Watch, Amnesty International, FIDH, LICRA, and Survie.

${ }^{35}$ These associations were the French Organization for the Promotion of Universal Jurisdiction, the CPCR, and Fondation Hirondelle.

${ }^{36}$ Another trial was observed using the same methods: that of Octavien Ngenzi and Tito Barahira, who on 6 July 2016 were found guilty of crimes against humanity and of genocide and sentenced to life in prison. I spent an approximate total of 1,000 hours (over the course of five months) in the courts.

${ }^{37}$ These data were collected for a separate study on defence lawyers, which is based on a quantitative analysis of their personal career trajectories.
} 


\section{4 | AN ENROLMENT PROCESS: HOW ORDINARY ACTORS CREATE A TJS}

\section{1 | Local passions}

Academic accounts of the successes and failures of UJ have, like descriptions of vernacularization processes, been contributed both by true believers and partisan actors forming advocacy communities $^{38}$ and by guardians of nations' sovereignty determined to defeat these efforts. The emergence of an international justice is seen as the result of civil society's efforts. For Roht-Arriaza, 'the Pinochet effect' would not have existed without 'the amazing synergy generated by victims' groups and NGOs', for instance. ${ }^{39}$

The rare empirical studies dedicated to UJ processes usually concentrate on remarkable stories - that is, dramatic narratives with many twists and turns but few happy endings. They privilege either historical timelines focused on legal and political decisions and counter-decisions or interviews with single-minded players. ${ }^{40}$ They tend 'to focus on the spectacular successes and catastrophic failures'. ${ }^{41}$ There is not much room in such stories for ambivalence, wavering, and contradictions. Victims, tenacious lawyers, and imaginative judges are featured reinventing the law on the basis of universalist values. ${ }^{42}$ Even the disenchanting stories proposed by Bourdieusian sociologists focus on strategists acting as transnational brokers of neoliberal norms. ${ }^{43}$ International law is the product of confrontations and collusions between firm believers and specialized players. In front of them, major criminals are protected by powerful states that they sometimes run.

Something of these epic confrontations remains in routine transnational trials. Many scholars see the French trials as a form of political trade-off, in connection with diplomatic tensions. ${ }^{44}$ Even though France did not colonize Rwanda, it has nevertheless played a significant role in the country's recent history. Historians and activists have reproached various governments for their lack of assistance to civilians who were then massacred, and indeed in some cases for an unwavering and fully cognizant support of an authoritarian government that was at least partially to blame for the genocide. ${ }^{45}$ Diplomatic tensions between France and Rwanda intensified after 1994, though are now decreasing. They were reflected at the judicial level in the proceedings brought by a French judge against high-ranking Rwandan officials, including President Paul Kagame himself.

In the case studied, professionals faced mid-level alleged criminals, with the consent of both governments. The Rwandan government vainly requested for Simbikangwa to be extradited from France to face justice in his country of birth. This conflict could explain the delay between the first complaints, in 1995, and the opening of the first trial, in 2014. Forced to take on the cases

\footnotetext{
${ }^{38}$ Keck and Sikkink, op. cit., n. 26.

${ }^{39}$ N. Roht-Arriaza, The Pinochet Effect: Transnational Justice in the Age of Human Rights (2005) 211.

${ }^{40} \mathrm{Id}$.

${ }^{41}$ E. Holzer, 'What Happens to Law in a Refugee Camp?' (2013) 47 Law \& Society Rev. 839.

${ }^{42}$ R. Brody, 'Bringing a Dictator to Justice: The Case of Hissène Habré' (2015) 13 J. of International Criminal Justice 210.

${ }^{43}$ Dezalay and Garth, op. cit., n. 30.

${ }^{44}$ F. Piton, Le génocide des Tutsi du Rwanda (2018) 172.

${ }^{45}$ B. Collombat and D. Servenay, Au nom de la France (2014).
} 
following criticism from the European Court of Human Rights in June 2004, ${ }^{46}$ the French judicial system (linked to the government through the office of the public prosecutor) would have preferred to avoid controversy. President Emmanuel Macron has recently, in May 2021, recognized the 'heavy responsibilities' of the French state. Those being tried were Rwandans, but top French political leaders (who were heads of government at the time of the genocide) might also be indicted.

Trials under UJ not only perpetuate a diplomatic conflict, but also prolong small domestic political wars. Political passions contributed greatly to the vernacularization process in the case of the Simbikangwa trial, perhaps detracting from 'the necessary serenity'. ${ }^{47}$ The controversy impacted the hearings, even though it could not be addressed too openly in the courtroom the case under consideration being unrelated to this political issue. The proceedings were in France the result of long-term transnational mobilizations. Various causes were defended, but unlike the 'diagnostic struggles' of the TLO theory, when contesting parties to legal change compete with each other in order to legitimate their diagnoses - not all of these causes were directly related to what was being tried (that is, the genocide committed by Rwandans against other Rwandans). In fact, some actors appropriated the trials to defend their own, more local purpose: some of the civil plaintiffs were advocating for the punishment of genocidaires, and others for human rights, against racism, or for the reform of French policies in Africa. These sometimes very strong disagreements resonated in the courts. In the same way, lively confrontations pitted historians and journalists against one another as they defended contrasting views of the genocide against the Tutsi and of the role played by France in Rwanda, fed by their knowledge as well as their proximity to Rwandan and French circles of power, their moral position, and their political alignment.

UJ trials have echoed political tensions, as generally do the vernacularization process or TLO building, but through the filter of ordinary routines and local disputes. Local unspecialized actors did much to build a transnational justice. This observation applies to trials under UJ as much as it does to other forms of trial of the perpetrators of the Tutsi genocide, incidentally. In Rwanda, semiprofessional lawyers were quickly trained to compensate for the lack of barristers, many of whom were killed for being Tutsi. ${ }^{48}$ Even the ICTR recruited many counsels with no prior experience of international proceedings and crimes against humanity because they were able to speak two languages or to understand common as well as continental law. Many of the defence counsels were Cameroonian or Canadian. The same has happened in the diverse European countries that have initiated UJ proceedings. Many asylum lawyers, business law or defamation specialists, and even general criminal lawyers defended members of the local Rwandan diaspora. In a similar way, many of them were court-appointed counsels with no prior interest in Rwandan affairs or international penal law. Indeed, these trials appear, when one takes the time to observe them, to be fairly ordinary and local scenes of justice. The building of a TLO is not simply a matter of normative concordance at different vertical levels; it is also a matter of horizontal extension to other issues and social sectors.

\footnotetext{
${ }^{46}$ ECHR, Affaire Mutimura c. France, Requête no. 46621/99, Arrêt Strasbourg [8 June 2004], at $<$ https:// hudoc.echr.coe.int/eng/\#\{“itemid”:[“001-66368”]\}>.

${ }^{47}$ H. L. Trouille, 'France, Universal Jurisdiction and Rwandan Genocidaires: The Simbikangwa Trial' (2016) 14 J. of International Criminal Justice 202.

${ }^{48}$ K. McCourt, 'Judicial Defenders: Their Role in Postgenocide Justice and Sustained Legal Development' (2009) 3 Inter-national J. of Transitional Justice 272.
} 


\section{2 | New non-partisan advocates for international justice}

UJ is a decentralized form of justice, rather than the top-down implementation of international law by international organizations (even though the ECHR and the ICTR have played an important role). Indeed, it engages and mobilizes local stakeholders. Universal political passions and moral shocks alone do not explain the interest in prosecuting foreign nationals. The people involved denounce the crimes against humanity, but they do so especially by continuing to assert their own claims and routines. TLO and vernacularization theories focus on the role played by activists or 'promoters and obstructers of TLOs', who either support or oppose the proposed 'order'. ${ }^{49}$ The Rwandan trials have brought together people from various sectors, who have worked more or less as usual and played the 'games' that they play in their regular cultural, social, and professional environments. More routine motivations or external incentives have thus contributed significantly to the success of UJ, compared to the first UJ trials based on the defence of major causes (in Belgium). Human rights defenders, academics, and judges in effect defend both a universal cause and their local 'professional jurisdictions' - that is, their own areas of legitimate professional expertise. ${ }^{50} \mathrm{UJ}$ is 'remade in the vernacular' precisely by echoing a diversity of local ordinary worlds in the fields of academia and law, in France and internationally. The process widens the network of advocates of a decentralized justice.

Rwandan trials have in particular been used to transform the French judicial system. The Simbikangwa trial was also the first prepared by the Pôle crimes contre l'humanité, crimes et délits de guerre (Crimes against Humanity and War Crimes Unit, created in 2012). It was a litmus test for both the office of the public prosecutor and the investigating judges of this unit. UJ has therefore been a front where the fight for and against the specialization of French judges (who today still have to be versatile) has taken place. New professional courts have since been established. On 23 March 2019, a law was adopted, merging the Pôle and the Anti-Terrorism Unit at the prosecution and police levels. The new unit now has jurisdiction to investigate war crimes, crimes against humanity, genocide, torture, and enforced disappearance. ${ }^{51}$ For instance, Islamist terror trials are now judged in Paris by a higher criminal court specially constituted for this purpose. ${ }^{52}$

UJ trials have also enabled the Pôle to create an international training network including the ICC as well as many foreign courts. In addition, in 2013 the Office central de lutte contre les crimes contre l'humanité, les génocides et les crimes de guerre (Central Office for Combatting Crimes against Humanity, Genocide and War Crimes) was created, where gendarmes and police officers investigate these human rights violations, including those committed abroad by foreign nationals. At the end of 2018, it had 19 agents for 102 criminal investigations. National institutional issues have fostered the vernacularization of international law.

Besides specialized judges and police officers, and together with long-time activists advocating for various causes, UJ has engaged other less internationalized professionals. While prominent human rights lawyers opened the Simbikangwa trial but soon left, other lawyers came by chance and stayed. Ordinary judges entered the courtroom. The previous day, they might have been presiding over a hearing in a case of bribery or domestic violence. Some of the victims' lawyers knew

\footnotetext{
${ }^{49}$ Halliday and Shaffer, op. cit., n. 29, p. 487.

${ }^{50}$ A. D. Abbott, The System of Professions: An Essay on the Division of Expert Labor (1988).

${ }^{51}$ Loi no. 2019-222 du 23 mars 2019 de programmation 2018-2022 et de réforme pour la justice (1), Art. 63 IV.

${ }^{52}$ S. Weill, 'Transnational Jihadism and the Role of Criminal Judges: An Ethnography of French Courts' (2020) $47 \mathrm{~J}$. of Law and Society S30.
} 
extradition or migration law better than international law; it is the same in other European countries. Many other ordinary people contributed to the conduct of the trials: court bailiffs, police officers, journalists, and the public. The setting, the working habits, the court proceedings, and many of the people in the room are therefore commonplace in the French judicial system.

Long-term collaborations and new friendships were forged on this occasion. Newcomers -not all partisan actors - have also become engaged stakeholders. For example, the trial led to the participation of two young court-appointed defence counsels who were specialized in commercial law and had consequently had little reason to dwell on cases subject to UJ. Nevertheless, they both became actively involved in the trial, partly because it brought them public visibility, but also for more personal reasons. Fabrice Epstein, for example, came from a family that was directly affected by the Holocaust and made a student trip to post-genocide Rwanda. It was in his own opinion ironic that he should become an attorney to the genocidaires. ${ }^{53}$

During the trials, relationships between the actors became tense. Such hostilities may do more to advance the cause of UJ than a completely vernacularized and universal legal language because, by impassioning activists and professionals, they often involve them for the long term in causes that are arduous, technical, poorly remunerative, and even frustrating and painful. This involvement has contributed to the success of UJ, which has become a means of professionalizing and acquiring new competencies, as well as championing a political or moral cause. Those actors who got involved by chance or in the exercise of their usual jobs in France are in many cases becoming specialists. Some of the historians consulted have, since the trials, specialized in genocide studies, while court-appointed lawyers have made every effort to attract new clients involved in proceedings related to the genocide against the Tutsi. They have surreptitiously become active defenders of the extension of UJ in France. Alongside the universal struggles related to human rights and the prosecution of crimes, local passions and routines are indeed the main drivers of the universalization of justice. ${ }^{54}$ While TLO and vernacularization theories have focused on vertical processes of norm settling, which are not linear but coherent in terms of the actors' motivations, what I discovered is the role of diversified horizontal networks in the building of a TJS.

\section{A TJS OF FRICTIONS AND COLLABORATIONS}

\subsection{Frictions between distant worlds}

In addition to French people engaged in their daily routines, other communities have participated in the trials: the diasporas in France and Belgium, but also transplanted past and present neighbourhood communities from the north of Rwanda and from Kigali, the capital city of Rwanda. Dozens of witnesses came from various countries, especially from Rwanda. Furthermore, the Simbikangwa trial took place before the Cours d'Assises in Paris and then in Bobigny for appeal proceedings. Groups of six French citizens (nine on appeal) and three judges met for six weeks or more. Juries of citizens selected at random from the electoral roll then issued verdicts on crimes against foreigners committed outside the territory of France by foreigners who were nevertheless living in France. How can we account for these encounters between very diverse national, cultural, professional, and social worlds, and for their effects on the way in which justice is

\footnotetext{
${ }^{53}$ Interview with the author, October 2014.

${ }^{54}$ C. Wilke, 'A Particular Universality: Universal Jurisdiction for Crimes against Humanity in Domestic Courts' (2005) 12 Constellations 83.
} 
rendered? Rather than confrontations, what we have witnessed are frictions between various social worlds and a hybridization between law and politics. ${ }^{55}$ This is too often skimmed over in a literature that focuses on the struggle between cause lawyers and states' guardians, ${ }^{56}$ and not analysed in depth by the TLO and vernacularization theorists.

We could, as critics of the neo-colonial legal order do, emphasize the asymmetries between people of different nationalities. ${ }^{57}$ The distance between French people and Rwandans, or between members of a social elite and people without wealth or education, is such that one is indeed tempted to read these events as a story of domination. Rwandan witnesses experienced a situation of dizzying social asymmetry. Having had just stepped off a plane after a 12-hour flight from Kigali, these people - who often live a life of toil and poverty - were lodged together in a hotel in Paris. The clothing appropriate to court was sometimes provided by the French state. In a country with which they were unfamiliar, they were instantly confronted with the protocols of imposing courtrooms. They waited long hours to testify, standing before a packed courtroom, and they were required to comply with proceedings that were hard for them to understand. Notably, they were hosted by the very same services engaged in justice for migrants and asylum seekers, and were consequently perceived by some members of the audience as migrants.

However, an interpretation in terms of Global North domination is reductive. The social realities that became linked through this trial under UJ cannot be so readily characterized in terms of global unified hierarchies. ${ }^{58}$ The relationships of domination that do exist reflect, first and foremost, local hierarchies. The poorly educated, working-class jury assembled to hear the Simbikangwa appeal in Bobigny, a poor suburb of Paris, was thus the subject of condescending remarks in the hallways by legal professionals, who were concerned about the jurors' ability to understand what was at stake in this trial. ${ }^{59}$ French social hierarchies were very present.

Foreign courts spend a great deal of time trying to overcome the filters and obstacles that separate the many social realities in question. What was observed in Paris or Bobigny was therefore less a jurisdiction made universal - a point of convergence between languages, laws, and conceptions of humanity - than a jurisdiction simultaneously situated in various spaces. The most obvious obstacle was clearly language. To a legal jargon that is hard to understand, one must add a language that is incomprehensible to most, Kinyarwanda. For some of the judges and academics, the names of witnesses were unpronounceable. Translators took turns, at times working in tandem. These translations affected the ability of a testimony to become evidence. For example, the court, in asking about the number of weapons stockpiled by Simbikangwa, discovered late in the process that the word for 'rifle' has no plural form in Kinyarwanda, and that this was the source of a persistent ambiguity surrounding the defendant's role: did he possess one rifle, or did he stockpile a large number of rifles at his house that were distributed later to perpetrators? Similar

\footnotetext{
${ }^{55}$ Langer, op. cit., n. 17.

${ }^{56}$ Tsing, op. cit., n. 25.

${ }^{57}$ Cowell, op. cit., n. 19.

${ }^{58}$ Dezalay and Garth, op. cit., n. 30.

${ }^{59}$ These remarks were made either in front of the author or in discussion with her. The poverty rate is 36 per cent in Bobigny, compared to 16 per cent in the capital and in a municipality of comparable size in the wealthier western suburbs. INSEE, 'Comparateur de territoire: commune de Bobigny (93008)' INSEE, at <https://www.insee.fr/fr/ statistiques/ 1405599?geo=COM-93008+COM-75056+COM-92023 $>$. The author assisted in the selection of the jurors and was aware of the profession of most of them.
} 
misunderstandings occurred during the ICTR proceedings, when the court did not understand that the word 'marriage' signified rape. ${ }^{60}$

Kinyarwanda and French were not separate languages, though, as the witnesses heard and occasionally spoke French; many Rwandans speak French, as Rwanda was a Belgian Frenchspeaking colony until 1961. At times, they intervened to correct what a translator, counsel, or judge had retained from their statements. This interference cast doubts on the power of domination in these judicial interactions; translators act as filters. Translation processes sometimes seem more complex than vernacularization.

These moving linguistic filters were accompanied by different senses of both time and space. Twenty years after the events, at what point does a witness who confuses months and years cease to be credible? How does one keep track of the past and of one's own disorientation at the time when the genocide took place? The witnesses' sense of space was also called into question. Even though the civil plaintiffs explained that the plans were not perfect because they were drawn up by a man on the move and not adapted from a map, the journey times between cities and regions and, therefore, the defendant's schedule - remained hard to assess. Similarly, the social structuring of space was subject to lengthy discussions. For example, how does one explain that in Rwanda a guest never ventures past the living room, and is therefore unable to say what might be stored in the kitchen or the bedroom?

Nuance was also given to the understanding of ethnic categories that had previously been viewed as rigid. For instance, how does one explain that ethnicity is passed on through the father, recorded on identification documents, and thus binding, but that at the same time it is often mixed and can be renegotiated or occasionally sidelined in favour of a clan identity common to both identities, as shown by Fujii? ${ }^{61}$ Even peoples' names and identities lose the stability that they have in one world when they enter another. The questions to the witnesses and the exchanges frequently involved unstable names and uncertain affiliations, as parents in Rwanda do not pass on their names, and instead assign new ones of their own invention. The court that tried Simbikangwa in the first instance had to give him a name; the charge was in fact made against one 'Mr. Safari Senyamuhara alias Pascal Simbikangwa'. This act of naming immediately became a measurement of the truthfulness of the statements of a man who had petitioned for the right to asylum and had then been convicted for fabricating many identification documents. Furthermore, the defendant constantly questioned the identity of the witnesses for the prosecution, claiming that activists from Ibuka, the Rwandan survivors' organization, had usurped the identities of his neighbours. When distinct worlds coexist, the identities of individuals are no longer readily intelligible reference points. As we will see, such uncertainty has consequences when it comes to judging a crime genocide - that is defined in relation to the identity of the target group.

The stories of witnesses were hard for people attending the hearings to decipher. The way in which these witnesses inhabited their roles did not correspond to the audiences's expectations or strict legal categories. Eyewitnesses could say that they did not have any evidence concerning the defendant. Expert witnesses, who were there to provide general knowledge, could nevertheless incriminate the defendant. This was, for example, the case with Belgian political scientist Filip Reyntjens, who was summoned by the defence as an expert, but who asserted that Simbikangwa was a member of powerful circles. Eyewitnesses, for their part, included 'guilty victims'. Two Tutsi witnesses in particular had clearly managed to escape the massacres by joining Hutu killers at

\footnotetext{
${ }^{60}$ J. Koomen, “"Without These Women, the Tribunal Cannot Do Anything”: The Politics of Witness Testimony on Sexual Violence at the International Criminal Tribunal for Rwanda' (2013) 38 Signs: J. of Women in Culture and Society 253.

${ }^{61}$ L. A. Fujii, Killing Neighbors: Webs of Violence in Rwanda (2009).
} 
the barricades, where many massacres were perpetrated; they were imprisoned for some time in Rwanda as members of the Interahamwe, a Hutu paramilitary group created by the former singleparty system. The public was thus disoriented by these roles, which were much more ambiguous and complex than what they expected in terms of a clear-cut moral dichotomy between killer and victim and between guilty and innocent. The complexity of social relationships and of roles during genocidal processes surfaced again and again. Personalities are not sufficiently consistent to prevent someone who is fundamentally moral from descending into violence one day, only to re-emerge as a rescuer the next. ${ }^{62}$

\section{2 | A TJS}

In the courts, there were encounters between social groups foreign to each other. The trials did not apply an international norm; they superimposed different local rules and references. Jurors with no legal background had to judge social interactions, between people in Rwanda and in the diasporas, that they did not fully understand. Their differences, as well as misconceptions about life in times of war, engendered misunderstandings. Symmetrically, the account of the facts was perceived, both by the judges and by the public, through the filter of the debate that was at the very same moment taking place in France, on the role played by its army and its governments during the genocide. However, it is precisely because of this polyphony that UJ gradually creates a TJS. This space is fragile and conflictual, but horizontal exchanges can make it 'thicker' than TLOs built through a vertical iteration of ideas.

From the investigation onwards, the proceedings were intertwined. Indeed, investigators from different national and international jurisdictions followed one another, which meant that the investigations of the former influenced those of the latter. Through these proceedings, UJ became the stable component of a decentralized justice, creating a network of courts. ${ }^{63}$ One of the more robust characteristics of this space was to link together testimonies filed before separate courts. Foreign judges came to testify about proceedings initiated elsewhere. The trial of four Rwandans held in Brussels in 2001 was a direct source of inspiration for the Paris trial. Witnesses travelled too. However, as with other instances of international justice, UJ was largely based on their testimonies, in a court operating 4,000 miles from where the crimes were committed. As a matter of fact, the documents, the sketches drawn by witnesses, and the photographs made by the police of streets and buildings described a country that exists 20 years after the facts, and that has undergone major upheaval during that time. What was being tried was mostly what was said in the here and now about events that occurred a long time ago.

In international jurisdictions inspired by common law procedure, the consistency of witnesses is tested through a long, hard cross-examination. In this respect, the large number of testimonies taken as a whole form evidence: 3,200 witnesses were heard at length by the ICTR (with more than 1,000 pages of hearing minutes per witness). There are no such checks and balances before the French Cour d'Assises. On the one hand, some 15 témoins de contexte (expert witnesses) came before the court in each trial to explain a context that was deemed hard for judges and juries to understand. These included historians, sociologists, legal experts, journalists, personality profilers, doctors, psychiatrists, and psychologists. Most were the same in the various trials. All were French people, who brought with them their everyday interests, causes, rationales, and conflicts.

${ }^{62}$ Id.

${ }^{63}$ A. Cassese (ed.), Realizing Utopia: The Future of International Law (2012). 
On the other hand, between 30 and 65 eyewitnesses testified on the facts at each trial. Farmers who came for the occasion from Rwanda and members of the Rwandan diaspora in Belgium and France were summoned to recount their own experiences. The interactions between the various parties, and the different pasts that they brought to life, determined the course of the trial and the verdict.

This composite narrative is built through the network of justice that I described. UJ trials impose specific constraints on the witnesses. Before appearing in national courts, the witnesses were heard a number of times by Rwandan institutions as well as by international and foreign jurisdictions. Thus, the questions asked by judges focused on confronting witnesses with their own words, meaning their previous statements, specifically by publicly reading out portions of these statements. In a sense, witnesses were asked merely to be their own echo.

The same happened for the victims. As a matter of fact, in the Simbikangwa trial, these were not victims of the defendant, but victims of the genocide who held the title of expert witnesses or civil plaintiffs. As survivors or as people who lost most of their family members, Spéciose Mukayiranga, Aline Kagoyire, and Dafroza Gauthier (the co-founder of the CPCR) thus played the expected role of victim; they recounted what they experienced when they were being pursued, or said the names of their dead relatives aloud. They did so before several tribunals in the same way that they had done so to the media and in their writings. These witness "careers" ${ }^{64}$ had an effect on the formulation of a narrative that was admissible for the court, as the concordance of the testimonies given in different places constituted the standard of truthfulness. UJ is made from this dense fabric of interwoven narratives.

\section{6 | TO JUDGE A GENOCIDE, DO WE NEED A(N) (EVIL) SUPERIOR?}

\section{1 | Normative misalignments}

While they are often supposed to contribute to an 'internationalization of crime' as well as to a 'supranational sensibility', UJ trials are still determined, along with the interwoven fabric of testimonies that I previously mentioned, by domestic law and procedures. ${ }^{65}$ For that reason, torture was removed from the charges against Simbikangwa, for example. ${ }^{66}$ How can a court describe a foreign genocide on such a basis? How can it achieve a complete vernacularization of the notion, or the 'normative concordance' at transnational, national, and local levels identified by TLO theory ${ }^{67}$ Though a category forged in international fora, and the 'worst of the crimes', genocide is not easy to judge. There are serious disagreements over the definition of target groups; the 1948 Convention on the Prevention and Punishment of the Crime of Genocide states that only cultural, ethnic, and religious groups can be considered victims of genocide, while domestic laws in France

\footnotetext{
64 'A career [is] composed of the progressive changes that occur in the beliefs that he has concerning himself and significant others' in a coming and going of the self within its social environment: E. Goffman, Asylums: Essays on the Social Situation of Mental Patients and Other Inmates (1968) 14.

${ }^{65}$ J. Cockayne, 'On the Cosmopolitanization of Criminal Jurisdiction' (2005) 3 J. of International Criminal Justice 514.

${ }^{66}$ The investigating judge considered that, in the absence of prosecution of the facts by a competent authority, the tenyear limitation period applied. See Cour d'Appel de Paris, Ordonnance de requalification, de non-lieu partiel et de mise en accusation devant la Cour d'Assises, Instruction no. 2425/12/22, 18-23 [2013].
}

${ }^{67}$ Halliday and Shaffer, op. cit., n. 29, p. 477. 
may define them 'on the basis of any other arbitrary criteria'. ${ }^{68}$ Another important issue concerns the definition of the intent to destroy the target group. How to prove this intention? Is it necessary to prove that each individual 'clearly intended the result'? Or are they guilty because they 'knew or should have known that the act committed would destroy' the group ${ }^{69}$ Indeed, is it necessary to demonstrate that the genocide was committed on the basis of a 'concerted plan', as required by the French Criminal Code, which echoes a definition based on the politics of the Third Reich? These discrepancies result in very disparate local definitions.

In particular, the category of genocide runs into the difficulty of establishing personal liability for participation in a collective process. How does one convict someone of genocide who is being tried on their own, as an individual? How can one characterize the ties between the participants when they are not members of an organized criminal gang or an administrative or military hierarchy, but instead form an 'unstructured group'? ${ }^{70}$ A genocide is neither the mechanical application of a state decision, nor an aggregation of racist murders committed by people filled with hatred. In the eyes of social scientists, genocide can simply consist of broad, rapid, and similar acts involving different groups that confirm the existence of a collective organization. ${ }^{71}$ The ICC's Elements of Crimes similarly defines genocide by murder as a 'manifest pattern of similar conducts' 72 that would not have been committed otherwise. ${ }^{73}$ Demonstrating this is nevertheless complicated, even if legal doctrine has begun to question central notions such as intention and purpose. ${ }^{74}$

UJ trials can reveal, and even exacerbate, a misalignment with international law. ${ }^{75}$ In this instance, time pressure, local law and procedure, and the moral dramatization necessary for the public justification of costly trials had a negative effect on the definition of genocide against the Tutsi. ${ }^{76}$ Although specialized judges and some civil party lawyers had real expertise in international crimes, international jurisprudence and concepts (such as the notion of superior responsibility) were hardly mobilized during the debates before the Cour d'Assises. Efforts were focused on adapting the stories to local legal categories forged by history.

In fact, the acts alleged to have been committed by Simbikangwa - distributing weapons and giving encouragement or instructions to the killers in the neighbourhood - did not meet the description of the processes of social adjustment that constitute genocide. The courts resolved this difficulty by outsourcing the demonstration of the evidence to the ICTR as a 'fact of common knowledge'. However, this did not settle everything, especially because the alleged acts were

\footnotetext{
${ }^{68}$ French Criminal Code, Art. 211-1.

${ }^{69}$ P. Akhavan, 'The Crime of Genocide in the ICTR Jurisprudence' (2005) 3 J. of International Criminal Justice 989.

${ }^{70}$ Fisher, op. cit., n. 9.

${ }^{71}$ H. Welzer, 'On Killing and Morality: How Normal People Become Mass Murderers' in Ordinary People as Mass Murder-ers: Perpetrators in Comparative Perspective, eds O. Jensen and C.-C. W. Szejnmann (2008) 165.

${ }^{72} \mathrm{ICC}$, Elements of Crimes (2011) Art. 6(a), element 4, at <https://www.icc-cpi.int/nr/rdonlyres/ 336923d8-a6ad-40ec-ad7b-45bf9de73d56/0/elementsofcrimeseng.pdf>.

${ }^{73}$ T. Isaacs, 'Individual Responsibility for Collective Wrongs' in Bringing Power to Justice?, eds J. Harrington et al. (2006) 18; Fisher, op. cit., n. 9, p. 74.

${ }^{74}$ A. K. A. Greenawalt, 'Rethinking Genocidal Intent: The Case for a Knowledge-Based Interpretation' (1999) 99 Columbia Law Rev. 2259; K. Ambos, 'What Does “Intent to Destroy” in Genocide Mean?' (2009) 91 International Rev. of the Red Cross 842 .

75 'The process of vernacularization can produce ideas and practices antithetical to human rights ideas themselves': Merry and Levitt, op. cit., n. 30, p. 165.

${ }^{76}$ The duration of the proceedings was similar to that of the major French assizes trials, in contrast to the very lengthy trials before international courts: around two months of trial versus 15 months before the ICC.
} 
characterized by various forms of complicity, which is, in the case of genocide, nevertheless considered as direct liability (Simbikangwa was for that matter recharacterized as a perpetrator). The Cour d'Assises showed itself capable of removing the main obstacle in the trial; the grounds for Simbikangwa's conviction on appeal stated that 'without there being a need to prove the involvement of a government authority, the concerted plan can be understood as the result of an informal group's action that may be organized, but that is distinct from any government authority. ${ }^{17}$

The court tried to consider the collective nature of the crime of genocide, such as through its mechanisms. During the initial trial, the Deputy Prosecutor used the map of the barricades to show how the genocide was coordinated. Starting on 7 April 1994, they were erected at all major intersections in all of the neighbourhoods in Kigali where the massacres began, and they were then deployed across the country's road network. Operated mostly by civilians, the barricades placed at strategic intersections were commanded by Hutu militants and supplied with munitions by police and municipal authorities. People had to show their ID cards, which stated ethnic affiliation. Many Tutsi were killed on the spot. Simbikangwa was found guilty of exercising an influence deemed to be extensive through his encouragement of barricade guards.

The French legal definition of the crime of genocide, constructed with reference to the extermination policy of the Nazi state, was tested on this occasion, and in part transnationalized, to take greater account of the collective nature of the crime. This dimension was partly obscured, nevertheless. As we shall finally see, the undisputed use of French proceedings has prevented a complete normative alignment. ${ }^{78}$ Instead of contributing to a unified international definition of the crime of genocide, the trial disseminated a less sophisticated conception of intent, in front of an audience inclined to a moral understanding of the facts.

\subsection{A portrait of a monster in a society gone crazy}

This difficulty in thinking about genocide as a collective dynamic, rather than as a sum of individual racist acts, was made clear when the court set out to identify the relationships between Rwandans at the time of the genocide. The testimonies of and brief exchanges between the witnesses shed light on certain aspects of social relationships in the Rwanda of 1994 and of the present day. Simbikangwa's superiors in the security forces tended to discredit the defendant in reaction to questions from the Presiding Judge that had accorded him significant power. At the same time, the testimonies by house guards and those who manned the barricades consisted mainly of assessing the social distance that separated them from the defendant, in this rich neighbourhood of Kigali. These relationships were not always easy to comprehend for the French public, who saw close domestic ties, but who could not understand, for example, that these guards never set foot in their bosses' homes or did not even know their names. Ordinary social relationships in Rwanda inspired misunderstandings and legal doubts.

The recounting of the events of 1994 thus allowed for the description of ordinary human links. Valérie Bemeriki, a presenter for Radio-Télévision Libre des Mille Collines and an active instigator of the massacres, described (on a screen, from her prison cell in Mali) the friendly banter at barricades as bodies were nevertheless piling up. Simbikangwa's defence counsel disputed her testimony as incongruous; is it possible to talk amicably in times of war? In fact it is, even as violence

\footnotetext{
${ }^{77}$ Cour d'Assises, op. cit., n. 32, para. 2. The existence of a concerted plan is requested by Art. 211-1 of the Code pénal (amended in 2004).

${ }^{78}$ Halliday and Shaffer, op. cit., n. 29.
} 
rages all around. ${ }^{79}$ Survivors often knew the defendants well, and had relationships with them, and still do today - relationships that could not always be reduced to mere rage or pain. Ambivalence was normal in the court. Repentant killers and propagandists incriminated the defendant, all the while saluting him courteously. ${ }^{80}$

Similarly, some of the men and women 'saved' by the defendant (who hosted some refugees in his house) said that they hoped he would be pardoned, while others said that they felt they were in the hands of a man who was able to decide on their death at any moment - a virtual killer, therefore. These interactions failed to neatly fulfil the expectations for these trials - namely, to separate the innocent from the guilty and to do justice to the pain of the victims. Isaïe H., a Tutsi survivor and barricade guard convicted in Rwanda, described in Kinyarwanda his attachment to the defendant, his former protector:

I loved him and he loved me too. Pascal was a respectable man and we all respected him. He had the power over life and death. He said, in speaking about me, 'This isn't the solution to the Tutsi problem.' ... He was a good neighbour. ${ }^{81}$

Relative to the chasm that now separates the survivors and the perpetrators of the genocide, such loyalty was inconceivable to civil plaintiffs. The civil party therefore presented the witness as 'the Tutsi' who belonged to the powerful Simbikangwa, 'a pet', or, in reference to the Bible, 'Isaïe, less than nothing, 82

Unlike the gacaca courts established in the very villages and cities where the acts were committed, and where everyone knows each other, foreign courts dramatized interactions. This did not facilitate the understanding of complex genocidal dynamics, where friendships and family ties did not prevent the murder. How could the jurors understand that during a genocide - which they rightly regarded as purely horrific - people can greet each other and talk more or less 'as normal'? Nevertheless, such a moralistic simplification has contributed to the transnationalization of the space of UJ, allowing a horizontal exchange of emotions. Discrepancies, then, do not necessarily prevent judicial spaces from functioning ${ }^{83}$ on the contrary, misunderstandings can be functional.

French criminal proceedings have largely contributed to the adoption of a simplistic definition of genocide. Inquiring into the personality of the accused is in fact an important phase of the assize court hearing. When the focus of criminal proceedings falls on individual intent, there is a major risk of inferring genocide from the personality of the alleged genocidaire, particularly from their constant, coherent personality, motivations, and ideology. This personalization was surely accentuated by the political context surrounding the trial; dwelling on the individual avoided the pitfall of incriminating states and high-ranking political officials. The Cour d'Assises, in trying genocide through one person, Simbikangwa, chose to define his status, meaning his position in the various social worlds. His liability was therefore established by demonstrating both his proximity

\footnotetext{
${ }^{79}$ P. Richards (ed.), No Peace, No War: An Anthropology of Contemporary Armed Conflicts (2005).

${ }^{80}$ Valérie Bemeriki concluded an accusation against the defendant defined as a 'planner' of the genocide with 'Greetings to Simbikangwa!' Notes from the 25 February 2014 hearing.

${ }^{81}$ Notes from the 28 February 2014 hearing.

${ }^{82}$ Expressions used by the CPCR in its daily chronicle: CPCR, 'Proces Simbikangwa 28 février 2014 partie 1' CPCR, 28 February 2014, at <http://www.collectifpartiescivilesrwanda.fr/proces-simbikangwa-28-fevrier-2014-partie-1/>.

${ }^{83}$ L. A. Payne, 'The Justice Paradox? Transnational Legal Orders and Accountability for Past Human Rights Violations' in Halliday and Shaffer, op. cit., n. 21, p. 439.
} 
and ideological adherence to the pre-genocidal and genocidal political powers, and his ability to influence the executioners.

However, the defendant - this 'shadowy captain' 84 - was ultimately hard to characterize: neither a civilian nor a soldier, ${ }^{85}$ having several last names, married but solitary, a father without a family, Hutu through his father and Tutsi through his mother, a 'rescuer' but also a facilitator and instigator of the genocide, a man of humble origins who was nevertheless tied to the rich clan of the Hutus in the north, a member of President Habyarimana's family without being close to him, an intellectual but also a torturer from the secret services, a powerful man confined to a wheelchair, a fugitive (in the eyes of the Rwandan government) and an illegal migrant (in the eyes of the French judicial system at the time of his arrest), a mid-ranking military official but someone who was very systematically supported by his hierarchy, a director without any office, and a proHutu party activist whose active involvement was unproven. Chance - or, rather, the excessive length of the proceedings - would have it that the first 'Rwandan trial' held in France concerned someone who was harder to try than François Bazaramba, who was sentenced to life in prison in Finland in 2010 and who not only held many formal titles but was described by witnesses as a direct perpetrator of the violence, and Jacques Munyaneza, who was convicted for many crimes that were reported by eyewitnesses and sentenced to 25 years' imprisonment in Canada in $2009 .^{86}$

For this reason, and given the lack of administrative documents, witnesses testified less about facts than about social relationships and memories that pointed to the importance of social, military, and political resources. The description of relationships - either with the relatives or with the killers - enabled the jury to decipher the social hierarchies and deferential behaviours. Witnesses described fewer actual actions than interactions, such as when a guard assigned to a barricade reported what another guard said about Simbikangwa: 'Careful, he has the power of life and death. He worked as part of a death squad ... Cross his path, and he'll kill you. ${ }^{87}$

The court was also able to recharacterize the crime of accomplice to genocide as a crime of genocide because it believed that it was dealing with an instigator. Simbikangwa, a man of uncertain identity, was presented as an intellectual, a man close to the circles of the genocidal power, an ideologue, and an activist in the Hutu Power clique. ${ }^{88}$ Witnesses described his participation in partisan meetings, his display of party emblems, and his role in media publications favourable to the Habyarimana regime. His writings, though ambiguous, were held up as evidence of his racism. For example, there was a long commentary on a passage from a book titled The October War, in which the defendant quoted his daughter, who at three years and ten months of age supposedly asked him the question 'Papa, are the Inyenzi dirty little people?'89

Other evidentiary resources were mobilized to construct the personality of a genocidaire. Simbikangwa's participation in the genocide was partially deduced from his personality. 'The conduct

\footnotetext{
${ }^{84}$ M. Malagardis, 'Rwanda: le capitaine de l’ombre face à des jurés français' Libération, 3 February 2014, at <http:// www. liberation.fr/societe/2014/02/03/rwanda-le-capitaine-de-1-ombre-face-a-des-jures-francais_977623>.

${ }^{85}$ At the time of the events, he had been relieved from duty following a car accident and assigned to the intelligence agency in 1988; although he was demoted when the multi-party government was formed in April 1992, he nevertheless appeared to have preserved, if not his status, at least his power.

${ }^{86}$ Kimpimaki, op. cit., n. 28; Currie and Stancu, op. cit., n. 28.

${ }^{87}$ Notes from the 6 March 2014 hearing.

${ }^{88}$ Hutu Power is a racist and ethnosupremacist ideology propounded by Hutu extremists in Rwanda. Different political parties belonged to it.

${ }^{89}$ P. Simbikangwa, La guerre d'octobre (1991) 9. 'Inyenzi' means 'cockroaches' in Kinyarwanda and is the name given to theTutsi in racist propaganda.
} 
and portrait of the defendant unsurprisingly involved traits shared with many genocidaires' namely, a radical animosity towards political enemies and a belief in relativist rhetoric and the spontaneous nature of civilian massacres. ${ }^{90}$ Testimonies that provided perceptions of his personality helped to demonstrate his liability; he was portrayed as an asocial, aggressive man capable of cold-blooded physical violence. As a man who could potentially be a genocidaire in a context in which many people were portrayed as killers, he was thus judged to actually be a genocidaire.

Acts of torture, though time-barred, ${ }^{91}$ were thus described at length in the analysis of his personality and career. Facts that appeared to speak for the defendant came to discredit him. His acts of rescue, which were not disputed, also became indicators of a passivity; he could have protected others. The testimonies of the 'protected' who took refuge in Simbikangwa's home and survived hindered rather than helped his cause, as they emphasized the ambivalence of his attitude, which was contradictory, not very benevolent, raging, and perhaps opportunist. The courtroom laughed when he claimed to be a just person.

Another resource that was heavily mobilized throughout the trial to prove Simbikangwa's participation in the genocide against the Tutsi was psychological and psychiatric profiling. All of the profilers analysed the defendant's personality in terms of a predisposition to engage in a process of political and ultimately genocidal radicalization. The psychology expert Bertrand Phésans stated: 'Considering the particulars of his personal history, he had all of the elements within him to be able to participate in the genocide. He was raised to hate the Tutsi. ${ }^{\text {'92 }}$ The previous day, his colleague Françoise Sironi portrayed the defendant as someone who was 'passionate about politics and thus prone to violence, vehemence, impulsiveness, and "disempathy"'. She emphasized two aspects that the Presiding Judge of the first court would frequently refer to thereafter: on the one hand, his separation anxiety and full allegiance to President Habyarimana, and on the other, his mixed-race identity, which led him to 'choose sides' and 'to reject his devalued half at the risk of engaging in terrorism or joining a totalitarian group' (which made a young, mixed-race woman sitting on the bench of the civil plaintiffs smile). ${ }^{93}$

The portrait was of an individual, but the traits indicated were perceived as markers of a genocidal personality forged in early childhood and during the genocide. Personal and political logic converged. Simbikangwa's defence - that he was passive - was thus demolished:

As concerns his political beliefs and his admiration for President Habyarimana, who represented an ideal father-figure to him, the Court believes that it is unlikely that he remained inactive ... This supposed inertia in effect exists in total contradiction with this personality, as he even portrayed himself as a leader of men who basically loved to command, which was the reason for his pursuing a military career.

The court found that Simbikangwa acted 'with the aim of the total destruction of this ethnic group that was held liable for the death of President Habyarimana, and which consequently represented to him a natural enemy that had to be exterminated'. ${ }^{94}$

\footnotetext{
${ }^{90}$ J. Hubrecht, Les leçons du procès Simbikangwa: une 'révolution judiciaire’ en marche? (2015) 6, at <http://docplayer.fr/ 65485984-Les-lecons-du-proces-simbikangwa-une-revolution-judiciaire-en-marche.html>.

${ }^{91}$ The investigating judge considered that, in the absence of prosecution of the facts by a competent authority, the ten-year

limitation period applied: Cour d'Appel de Paris, op. cit., n. 66.

92 Notes from the 14 February 2014 hearing.

${ }^{93}$ Notes from the 13 February 2014 hearing.

${ }^{94}$ Cour d'Assises, op. cit., n. 32, para. 8.
} 
The difficulty of constructing a reality shared by all of the stakeholders increasingly favoured an individualized and psychological understanding of the crime. Thus, despite the efforts of specialized judges to incorporate concepts of international law, explanations focusing on personality prevailed, even though the genocide should have been explained in terms of collective processes. A tense political context, the implementation of a new form of justice, and domestic proceedings resulted in an oversimplication of the facts constitutive of genocide.

\section{7 | CONCLUSION}

Did the Rwandan trials in Paris further the internationalization of law? The flourishing UJ may not have become more homogenized and standardized. TLO theory has shown how the building of a TLO is characterized by indeterminacy, contradictions, and struggles. However, the study of UJ highlights other dimensions of these processes. A TJS has been built that has not yet become a settled TLO, even though there is an apparent concordance of international, national, and local norms. Looking beyond the alignment of norms to consider the procedures and practices of law brings out the frictions. However, this is not a failure; as Payne has shown for the accountability of a TLO, disorders can serve the order: 'TLO settling might benefit from a certain amount of indeterminacy of law'. ${ }^{95}$ The space built by the networks of actors using UJ is now becoming routine. First, newcomers have been recruited. Ordinary lawyers and judges have added their strengths to those of human rights activists and experts, while serving their own professional causes and sometimes reforming the judicial system. Second, horizontal interactions between and within countries make this space work - rather than the vertical dissemination networks foregrounded by theories of vernacularization and TLO building. While the latter focus on IOs drafting regulatory rules, it is networked courts that construct this space through individual convictions. Intertwined testimonies and jurisprudences make trials possible. Third, the institutionalization of UJ has 'remade [international law categories] in the vernacular', to quote Merry, albeit filtered and distorted by local proceedings in this instance. ${ }^{96}$ Today, a TJS exists that cannot be described from above, top down and from the outside. It takes shape inside the courts, through a bottom-up process. To a certain extent, routine UJ and the principle of complementarity paradoxically do more for the integration of national legal systems than the primacy given to international law. The 'fragmentation' of international law may in fact strengthen it. ${ }^{97}$

\section{A C KNOWLEDGEMENTS}

I warmly thank the reviewers and the copy-editor, who have contributed greatly to improving this article through their enlightened and benevolent remarks.

How to cite this article: Lefranc, $S$. A tale of many jurisdictions: how universal jurisdiction is creating a transnational judicial space. J Law Soc. 2021;48:573-594. https://doi.org/10.1111/jols.12328

\footnotetext{
${ }^{95}$ Payne, op. cit., n. 83, p. 469.

${ }^{96}$ Merry, op. cit., n. 20, pp. 990-991.

${ }^{97}$ Schabas, op. cit., n. 14 , p. 613.
} 